\section{Prostate cancer-associated}

\section{thrombotic microangiopathy: A case report and review of the literature}

\author{
HHS Kharagjitsing ${ }^{1 *}$, PAW te Boekhorst ${ }^{2}$ and Nazik Durdu- \\ Rayman ${ }^{3}$
}

\begin{abstract}
'Department of Internal Medicine, Erasmus University Medical Centre, Rotterdam, The Netherlands ${ }^{2}$ Department of Hematology, Erasmus University Medical Centre, Rotterdam, The Netherlands ${ }^{3}$ Department of Internal Medicine-Hematology, Franciscus Hospital location Vlietland, Schiedam, The Netherlands
\end{abstract}

\section{Abstract}

Background: Thrombotic microangiopathy (TMA) is a rare and life-threatening complication of prostate carcinoma. Whether plasma exchange has a role in treatment remains a subject of debate. Here we present a case followed by a systematic review of the literature on this subject.

Case report: We describe a 69-year old patient presenting with TMA, which was associated with an underlying metastatic prostate carcinoma. We conducted a search of similar cases in literature.

Results: Our patient was treated and responded well on plasma exchange. Systematic review of the literature showed 17 additional cases of TMA associated with prostate carcinoma of which eleven were treated with plasma exchange with mostly good response.

Conclusion: Based on current data we cannot exclude a potential role for plasma exchange in prostate cancer associated TMA.

\begin{abstract}
More Information
*Address for Correspondence: HHS Kharagjitsing, MD, Department of Internal Medicine, Erasmus University Medical Centre, Rotterdam, The Netherlands, Tel: 010704 0704; Email: h.kharagjitsing@erasmusmc.nl; hardjit@hotmail.com

Submitted: January 12, 2021

Approved: March 04, 2021

Published: March 08, 2021

How to cite this article: HHS Kharagjitsing, PAW te Boekhorst, Durdu-Rayman N. Prostate cancer-associated thrombotic microangiopathy: A case report and review of the literature. J Clini Nephrol. 2021; 5: 017-022.
\end{abstract}

DOI: 10.29328/journal.jen.1001068

ORCiD: orcid.org/0000-0001-6450-3676 ORCiD: orcid.org/0000-0002-3566-5016

Copyright: () 2021 HHS Kharagjitsing, et al This is an open access article distributed under the Creative Commons Attribution License, which permits unrestricted use, distribution, and reproduction in any medium, provided the original work is properly cited.

Keywords: Thrombocytopenic purpurahaemolytic uremic syndrome; Prostate carcinoma Thrombotic microangiopathy; Plasma exchange
W) Check for updates
OPEN ACCESS

\section{Introduction}

Thrombotic microangiopathy (TMA) is characterized by endothelial dysfunction, leading to platelet thrombi with thrombocytopenia and microangiopathic haemolytic anemia (MAHA) due to mechanical injury of red blood cells in the microcirculation. Given the heterogeneity of underlying conditions associated with TMA, it has been suggested to classify primary or secondary TMA syndromes [1]. The most common form of primary TMA in adults is "A Disintegrin And Metallo- protease with ThromboSpondin-1-like domains" (ADAMTS13) deficiency mediated TMA also called thrombocytopenic purpura-haemolytic uremic syndrome (TTP). Other forms of primary TMA are complementmediated TMA, metabolism- mediated TMA, coagulationmediated TMA, Shiga toxin-mediated TMA and drugmediated TMA.

Since TMA may also be associated with several disorders, including metastasized malignancy, a thorough diagnostic work-up of these patients is indicated. In adults, given its life-threatening potential, treatment with plasma exchange and corticosteroids is usually promptly initiated. This is in contrast to Shiga toxin-mediated TMA where plasma exchange and corticosteroids have no role in the treatment.

Plasma exchange removes eventually autoantibodies while plasma replaces deficient ADAMTS13 and complement factors $[2,3]$.

In the Oklahoma TTP-HUS registry ten (3\%) of 351 patients, initially diagnosed as having TTP-HUS and treated with plasma exchange, were subsequently and unexpectedly diagnosed with disseminated malignancy [4]. This syndrome has been reported in various malignancies (e.g. gastric, lung, breast, lymphoma), including that of the prostate. Interestingly, in approximately $90 \%$ of the cases malignancy was metastatic at presentation [5].

Different hypotheses exist on the mechanism of cancer associated thrombotic microangiopathy (CA-TMA). Abnormal angiogenesis in the marrow, aggressive growth of tumours, and secondary myelofibrosis may all injure the endothelial cells [6]. The endothelial damage could then cause the release of ultra large VWF multimeres (UL-VWF) thereby leading to MAHA and thrombocytopenia. Others favor mechanical 
obstruction by tumour emboli or intraluminal fibrin thrombi $[7,8]$. Indeed, cancer microparticles may be involved in the initiation of CA-TMA [9]. whilst also activation of the coagulation pathway through tumour cell pro-coagulants like tissue factor and other cancer pro-coagulants, may contribute to the microvascular obstruction $[10,11]$. A specific mechanism is proposed for mucin generating cancers $[12,13]$. Carcinoma mucins generate platelet rich microthrombi through adhesion dependent, bidirectional signaling in neutrophils and platelets [14].

Both the indication for plasma exchange therapy, and the role of ADAMTS13 are not considered to play a role in CA-TMA [15]. We present a case of a metastasised prostate cancer associated with TMA recovering after plasma exchange, followed by a systematic review of the current literature on this subject.

\section{Case report}

A 69-year old man presented at the emergency department with a 4-day history of nausea, vomiting and malaise. There was no significant medical history nor was he taking any medication, including over the counter medicine, supplements or herbs. Physical examination revealed mild jaundice, no fever or hypertension and no signs of impaired coagulation or neurological dysfunction.

Laboratory results showed mild anemia with a negative direct antiglobulin (DAT) test, thrombocytopenia and renal failure (Table 1). Although coagulation tests showed increased d-dimers, fibrinogen was not decreased and no signs of deep venous thrombosis or fulminant disseminated intravascular coagulation were found. The peripheral blood smear revealed fragmentocytes (Figure 1).

Immediate treatment with plasma exchanges and prednisone was initiated. ADAMTS13 level obtained prior to plasma exchange -and reported a day post admissionwas not decreased (70\%). Given the latter, we decided to omit prednisone and continue plasma exchange after one day. Additional investigations revealed an adenocarcinoma (Gleason $4+5=9$ ) of the prostate with an elevated serum prostate specific antigen of $296 \mathrm{ug} / \mathrm{L}$ (normal < $4 \mathrm{ug} / \mathrm{l}$ ) with multiple skeletal metastases. After a total of seven sessions of plasma exchanges, the renal function, thrombocytes and lactate dehydrogenase recovered. The patient was prescribed biculatamide $50 \mathrm{mg}$ daily and was discharged from the hospital after seven days. At 2 years follow-up the TMA has not recurred and the patient was doing well with a stable renal function (creatinine $102 \mathrm{umol} / \mathrm{L}$ ) and PSA of 2.6 $\mathrm{ng} / \mathrm{ml}$.

\section{Discussion}

Previously reported cases were identified by searching PubMed and Embase databases (search strategy showed in

\begin{tabular}{|c|c|c|}
\hline Variable & On admission & Day 7 \\
\hline Hemoglobin $(8,1-11,0 \mathrm{mmol} / \mathrm{L})$ & $7.9 \mathrm{mmol} / \mathrm{L}$ & $5.2 \mathrm{mmol} / \mathrm{L}$ \\
\hline $\operatorname{MCV}(80-100 \mathrm{fl})$ & $87 \mathrm{fl}$ & $94 \mathrm{fl}$ \\
\hline $\begin{array}{c}\text { Platelet count } \\
\left(150-400 \times 10^{9} / \mathrm{L}\right)\end{array}$ & $36 \times 10^{9} / \mathrm{L}$ & $399 \times 10^{9} / L$ \\
\hline White blood cell count $\left(4.0-10.0 \times 10^{9} / \mathrm{L}\right)$ & $15.8 \times 10^{9} / \mathrm{L}$ & $10.6 \times 10 \% / L$ \\
\hline Haptoglobin $(0.5-3.0 \mathrm{~g} / \mathrm{L})$ & $0.08 \mathrm{~g} / \mathrm{L}$ & $2.9 \mathrm{~g} / \mathrm{L}$ \\
\hline $\begin{array}{l}\text { Reticulocyte count } \\
\left(25-100 \times 10^{9} / \mathrm{L}\right)\end{array}$ & $31 \times 10^{9} / \mathrm{L}$ & UA \\
\hline Urea (3,0-7,0 mmmol/L) & $29.9 \mathrm{mmol} / \mathrm{L}$ & $11.2 \mathrm{mmol} / \mathrm{L}$ \\
\hline DAT & NEGATIVE & UA \\
\hline $\begin{array}{l}\text { Bilirubin total } \\
(<17 \text { umol/L) }\end{array}$ & $39 \mathrm{umol} / \mathrm{L}$ & 7 umol/L \\
\hline LD $(150-300$ u/L) & $1279 \mathrm{u} / \mathrm{L}$ & $189 \mathrm{u} / \mathrm{L}$ \\
\hline ASAT (0-30 u/L) & $52 \mathrm{u} / \mathrm{L}$ & $16 \mathrm{u} / \mathrm{L}$ \\
\hline ALAT (0-30 u/L) & $22 \mathrm{u} / \mathrm{L}$ & $31 \mathrm{u} / \mathrm{L}$ \\
\hline Potassium (3.5-5.0 mmol/L) & $3.8 \mathrm{mmol} / \mathrm{L}$ & $4.5 \mathrm{mmol} / \mathrm{L}$ \\
\hline Fibrinogen $(1.74-4.0 \mathrm{~g} / \mathrm{L})$ & $3.9 \mathrm{~g} / \mathrm{L}$ & NA \\
\hline INR & 1.2 & 1.1 \\
\hline PT (10-13 sec) & $13.2 \mathrm{sec}$ & $12.6 \mathrm{sec}$ \\
\hline D-dimer (< $5 \mathrm{mg} / \mathrm{L})$ & $6.59 \mathrm{mg} / \mathrm{L}$ & $6.59 \mathrm{mg} / \mathrm{L}$ \\
\hline APTT (22-33 sec) & $28 \mathrm{sec}$ & $23 \mathrm{sec}$ \\
\hline Creatinine & $284 \mathrm{umol} / \mathrm{L}$ & $140 \mathrm{umol} / \mathrm{L}$ \\
\hline eGFR & $19 \mathrm{ml} / \mathrm{min}$ & $44 \mathrm{ml} / \mathrm{min}$ \\
\hline
\end{tabular}

MCV: Mean Corpuscular Volume; DAT: Direct Antiglobulin; INR: International Normalized Ratio; PT: Prothrombin Time; APTT: Activated Partial Thromboplastin Time; LD: Lactate Dehydrogenase; AF: Alkaline Phospathase; AST Aspartate Aminotransferase; ALT: Alanine Aminotransferase (Normal Range); UA: Unavailable

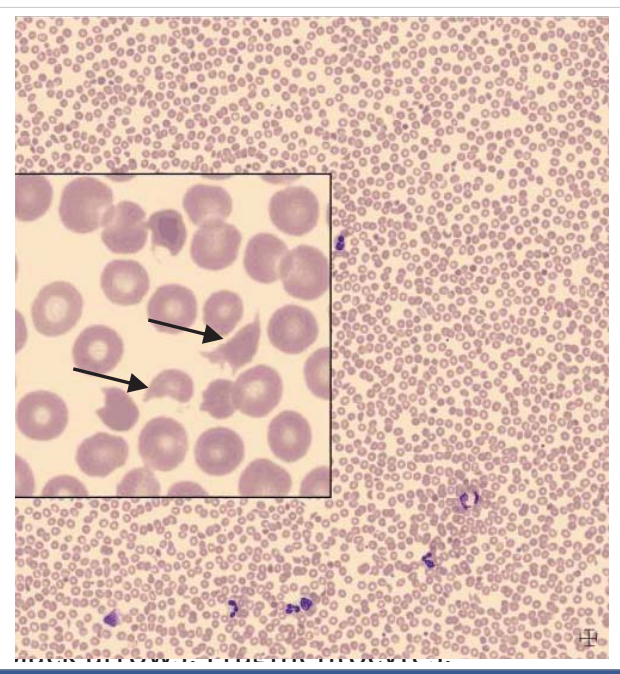

Figure 1: Black arrows: Fragmentocytes.

the supplement). We found 17 cases as summarized in table 2 . We excluded cases not available in English.

The main presenting symptoms were vomiting and oliguria secondary to renal failure.

Six patients were treated solely with dialysis; three patients received only plasma exchange [16-18]. Furthermore eight patients were treated with dialysis combined with plasma therapy (plasmapheresis or plasma exchange). Fourteen out of the seventeen cases showed full recovery after haemodialysis and/or plasma therapy after which hormone therapy was commenced. TMA recurred in three 
cases $[19,21]$. Two patients died due to disseminated disease $[16,17]$. one due to cardiac arrest [22].

Interestingly, Kanesvaran, et al. described a patient who was treated solely with anti-androgen therapy (Bicalutamide) [23]. Within two weeks the patient recovered both clinically and biochemically after which he started with LH-RH therapy. He was discharged four weeks after initiation with Biculatamide. Complete resolution of the symptoms, signs and biochemical findings of TMA, was noted. The patient died
8 months after his initial diagnosis with no signs of TMA at time of death.

Perkovic, et al. described a patient treated initially with plasma exchange and prednisone [24]. After 14 days when the diagnosis of prostate cancer became evident, plasma exchange and prednisone were ceased and he was treated with anti-androgen therapy with good response and no recurrence of TMA.

We presented a 69-year old patient with a DAT negative

Table 2: Cases in the literature.

\begin{tabular}{|c|c|c|c|c|c|c|c|}
\hline Author & Age & Presenting symptoms & $\begin{array}{l}\text { Coagulation } \\
\text { assays }\end{array}$ & Metastasis & Therapy & Outcome & FU \\
\hline Subramaniam, [18] & 57 & $\begin{array}{l}\text { Lack of energy, } \\
\text { petechiae }\end{array}$ & $\begin{array}{c}\text { Normal, } \\
\text { (ADAMTS13 } \\
\text { normal) }\end{array}$ & + & $\begin{array}{l}\text { PLEX } 9 \text { days, day } 5 \\
\text { leuprorelin, steroids }\end{array}$ & UA & UA \\
\hline Ramos, [44] & 72 & $\begin{array}{c}\text { Hematemesis, } \\
\text { hematuria, oliguria }\end{array}$ & $\begin{array}{c}\text { Normal (PT, } \\
\text { APTT, fibrinogen) }\end{array}$ & + & $\begin{array}{c}\text { 8x hemodialysis, } \\
7 \times \text { plasmapheresis, } \\
\text { bicalutamide, goserelin }\end{array}$ & Discharged after 15 days & $\begin{array}{l}\text { After } 18 \text { months no } \\
\text { recurrence }\end{array}$ \\
\hline Basic, [17] & 74 & UA & UA & + & PLEX & $\begin{array}{l}\text { Died from disseminated } \\
\text { disease }\end{array}$ & UA \\
\hline Caramello, [16] & $61^{*}$ & Confusion, lumbar pain & $\begin{array}{l}\text { APTT } 66(26-38), \\
\text { PT } 12 \%(70-130), \\
\text { fibrogen } 97 \mathrm{mg} / \mathrm{dl} \\
\left(\begin{array}{c}150-450), \mathrm{d}-\mathrm{dimer} \\
>800 \mathrm{ng} / \mathrm{ml}(< \\
230)\end{array}\right.\end{array}$ & + & $\begin{array}{l}\text { FFP, PLEX, iv hydration, } \\
\text { loop diuretics after } \\
\text { recovery chemotherapy }\end{array}$ & UA & $\begin{array}{l}\text { After } 26 \text { months no } \\
\text { recurrence }\end{array}$ \\
\hline Kanesvaran, [23] & 61 & Lethargy, haematuria & normal & + & $\begin{array}{l}\text { Bicalutamide, after } 2 \\
\text { weeks goserelin }\end{array}$ & $\begin{array}{l}\text { After } 4 \text { weeks complete } \\
\text { resolution of symptoms/ } \\
\text { biochemical findings of } \\
\text { TTP }\end{array}$ & $\begin{array}{c}\text { After } 8 \text { months patient } \\
\text { died (no signs of } \\
\text { TTP) }\end{array}$ \\
\hline Biers, [22] & 76 * & $\begin{array}{l}\text { Confusion, oliguria, } \\
\text { haematuria }\end{array}$ & normal & + & $\begin{array}{l}\text { Dialysis (obstructive } \\
\text { acute renal failure, } \\
\text { bladder invase } \\
\text { prostateca) }\end{array}$ & Death (cardiac arrest) & UA \\
\hline Mungall, [45] & $\begin{array}{l}-87 \\
\bullet \quad 83 \\
-76^{*} \\
-\quad 69^{*}\end{array}$ & $\begin{array}{l}\bullet \text { vomiting } \\
\text { - oliguria, haematuria } \\
\text { • vomiting } \\
\text { - oliguria, haematuria, } \\
\text { bruising, epistaxis }\end{array}$ & $\begin{array}{l}\text { - } \text { normal } \\
\text { - normal } \\
\text { - normal } \\
\text { - normal }\end{array}$ & $\begin{array}{c}\text { - haemodialysis, PLEX, } \\
\text { where after goserelin (after } \\
\text { - haemodialysis wehere } \\
\text { after goserlin/cypoterone } \\
\text { acetate } \\
\text { - haemodialysis } \\
\text { - haemodialysis , PLEX }\end{array}$ & $\begin{array}{l}+ \\
+ \\
+ \\
+\end{array}$ & $\begin{array}{l}\text { renal function improved } \\
\text { in all four cases, time to } \\
\text { recovery UA }\end{array}$ & UA \\
\hline Perkovic, [24] & 67 & backpain & normal & $\begin{array}{l}\text { PLEX, haemodialysis, } \\
\text { prednisolone, vitamin E, } \\
\text { after } 14 \text { days prostateca } \\
\text { was diagnosed, start } \\
\text { hormonal therapy, PLEX/ } \\
\text { prednisolone was ceased }\end{array}$ & + & $\begin{array}{c}\text { After } 6 \text { weeks } \\
\text { haematological, PSA } \\
\text { normalized }\end{array}$ & $\begin{array}{l}\text { After } 18 \text { months no } \\
\text { recurrence }\end{array}$ \\
\hline Muller, [46] & $61^{*}$ & jaundice, vomiting & Normal & - & 4xPLEX, 8 days dialysis & $\begin{array}{c}\text { Normalisation creat } 2 \\
\text { mo later, }\end{array}$ & $\begin{array}{l}6 \text { years later no } \\
\text { recurrence of HUS }\end{array}$ \\
\hline Innes, [19] & 79 & $\begin{array}{l}\text { Anorexia, jaundice, } \\
\text { malaise, anuria }\end{array}$ & Normal & + & Haemodialysis 3 weeks & $\begin{array}{l}6 \text { mo renal function } \\
\text { improved }\end{array}$ & $\begin{array}{l}9 \text { years later } 3 \\
\text { recurrences of HUS: } \\
\text { dialysis required in } \\
\text { the first } 2 \text { episodes }\end{array}$ \\
\hline Van der Merwe, [20] & $\begin{array}{l}-72 \\
\bullet\end{array}$ & $\begin{array}{l}\text { Anuria,haematuria, } \\
\text { confusion } \\
\text { - Loin pain, oliguria }\end{array}$ & $\begin{array}{l}\text { - Normal } \\
\text { - Normal }\end{array}$ & $\begin{array}{l}+ \\
+\end{array}$ & $\begin{array}{l}\text { Dialysis (peritoneal) } \\
\text { for } 1 \text { week, } \\
\text { aspirin,dipyridamol } \\
\text { Dialysis (peritoneal), } \\
\text { PLEX for } 8 \text { days, } \\
\text { aspirin,dipyridamol }\end{array}$ & $\begin{array}{l}\text { - After } 1 \text { mo recovery of } \\
\text { renal function } \\
\text { - After } 14 \text { days } \\
\text { recovery of renal } \\
\text { function/haematological } \\
\text { abnormalities }\end{array}$ & $\begin{array}{l}\text { - After } 4 \text { months } \\
\text { recurrence of HUS } \\
\text { treated with PLEX, } \\
\text { where after LHR } \\
\text { agonist } \\
\text { - TUR prostate }\end{array}$ \\
\hline Sennesael, [47] & 64 & $\begin{array}{l}\text { Lumbar pain, } \\
\text { haematuria, oliguria }\end{array}$ & Normal & + & \begin{tabular}{|c|} 
- first epidode: \\
conservative, after \\
9 days spontaneous \\
improvement of \\
laboratoriumvalues \\
- second episode $8 \mathrm{mo}$ \\
later: haemodialysis (3x)
\end{tabular} & $\begin{array}{c}\text { After } 10 \text { days } \\
\text { improvement of renal } \\
\text { function }\end{array}$ & $\begin{array}{l}\text { After } 12 \text { months no } \\
\text { recurrence of HUS }\end{array}$ \\
\hline Milutinovic, [47] & 62 & $\begin{array}{l}\text { Nausea, vomiting, } \\
\text { oliguria, haematuria }\end{array}$ & Normal & + & $\begin{array}{l}\text { 8x haemodialysis, } \\
\text { plasma, aspirin, } \\
\text { persantin }\end{array}$ & $\begin{array}{c}\text { After } 3 \text { mo laboratory } \\
\text { values recovered/clinic } \\
\text { improved }\end{array}$ & UA \\
\hline
\end{tabular}

*: Already known with prostate carcinoma.UA: Unavailable; PLEX: Plasma Exchange; FFP: Fresh Frozen Plasma 
fragmentocytic haemolytic anemia, thrombocytopenia and renal dysfunction, posing an indication to start plasma exchange (PE), given the presumed diagnosis of primary TMA. After one day the ADAMTS13 level turned out to be normal, whilst further analysis revealed a metastatic prostate carcinoma.

ADAMTS13, an enzyme that splits ultra large von Willebrand Factor (UL-VWF) protein and discovered in 1998 [25]. has a debatable role in treatment decisions in the clinical CA-TMA syndromes [26-36].

In just one of the described cases beside ours, ADAMTS13 activity was determined and was found within normal limits [18]. We didn't determine ADAMTS 13 antibodies, which could have masked an abnormal ADAMTS13 level, as is suggested to play a role in the pathophysiology [37].

Evaluation and treatment of the largely heterogeneous group of patients presenting with thrombocytopenia and microangiopathic haemolytic anemia is challenging. We believe that diagnosis and thereby treatment decisions in the whole spectrum of TMA, should not depend on ADAMT13 activity. Furthermore we consider it appropriate to initiate plasma exchange therapy when there is a suspicion of TMA. Although it has been argued that for remission of secondary TMA, the underlying disease should be treated, this is not unequivocally substantiated in the context of prostate cancer associated TMA [38,39].

The mechanism by which the prostate carcinoma induced the clinical manifestation of TMA in this case remains unclear. It is well known that prostate carcinoma may display a number of coagulation disorders. The most frequent coagulation disorder is disseminated intravascular coagulation (DIC). Other coagulopathies include TTP, thrombosis and acquired factor VII inhibitor development [40].

Possibly a low-grade DIC might have contributed to the clinical picture in this patient which subsequently responded to plasma exchange. In DIC, plasma exchange is hypothesized to remove different tissue factors, plasminogen activator inhibitor-1, tissue plasminogen activator inhibitor and replenish anti-thrombin III, protein C and S [41]. It is often a difficult balance between thrombosis and bleeding, sometimes even occurring at the same time in DIC. Patients may require pro-coagulants e.g. plasma therapy, vitamin $\mathrm{K}$ when bleeding. Platelet transfusions may be given for severe thrombocytopenia. Concurrently, low molecular weight heparin could be initiated, at least in a prophylactic dosage if the phenotype is predominantly thrombotic [42].

There is currently no consensus regarding indication, patient selection, method, timing and duration of plasma exchange for secondary TMA [41]. Treatment decisions are therefore complex. Especially since no intervention is risk free. Potential complications of plasma exchange include those related to insertion of the central line, catheter related infections, citrate toxicity and reactions to plasma [43].

To date there is no evidence available about treating cancer associated TMA with complement inhibitors, monoclonal antibodies or corticosteroids.

Management decisions in the TMA syndromes still prove to be very difficult and remain the responsibility of the clinician. We therefore stress the need for controlled documentation on the effect of various treatments modalities including plasma exchange in CA-TMA. Thereby including the still elusive role of ADAMTS13 and its antibodies, while working towards a standardized measurement assay.

\section{Conclusion}

We presented a 69-year old patient with a DAT negative fragmentocytic haemolytic anemia, thrombocytopenia and renal dysfunction, posing an indication to start plasma exchange (PE), given the presumed diagnosis of primary TMA. ADAMTS13 level turned out to be normal, whilst further analysis revealed a metastatic prostate carcinoma. The diagnosis of a full-blown disseminated malignancy was not initially apparent at presentation, but low-grade DIC might have contributed to the clinical picture. The patient fully recovered after seven sessions of plasma exchange. Considering the available data we, in contrast to some, cannot deny a potential role for plasma exchange in prostate cancer associated TMA.

\section{Acknowledgement}

We would like to thank Prof. A. Brand, MD-PhD (Department of Immune Haematology and Blood transfusion, Leiden University Medical Centre and Sanguin Bloodbank Leiden, The Netherlands) for her critical comments, contributing to improvement of the intellectual content.

\section{References}

1. George JN, Nester CM. Syndromes of thrombotic microangiopathy. N Engl J Med. 2014; 371: 654-666.

PubMed: https://pubmed.ncbi.nlm.nih.gov/25119611/

2. George JN. Clinical practice. Thrombotic thrombocytopenic purpura. N Engl J Med. 2006; 354: 1927-1935.

PubMed: https://pubmed.ncbi.nlm.nih.gov/16672704/

3. Tsai HM, Lian EC. Antibodies to von Willebrand factor-cleaving protease in acute thrombotic thrombocytopenic purpura. $\mathrm{N}$ Engl $\mathrm{J}$ Med. 1998; 339: 1585-1594.

PubMed: https://pubmed.ncbi.nlm.nih.gov/9828246/

4. George JN. Tibor Greenwalt Award. The Oklahoma Thrombotic Thrombocytopenic Purpura-Hemolytic Uremic Syndrome Registry: a program for patient care, education and research. Transfusion. 2004; 44: 1384-1392.

PubMed: https://pubmed.ncbi.nlm.nih.gov/15318866/

5. Lechner K, Obermeier HL. Cancer-related microangiopathic hemolytic anemia: clinical and laboratory features in 168 reported cases. Medicine. 2012; 91: 195-205.

PubMed: https://pubmed.ncbi.nlm.nih.gov/22732949/ 
6. von Bubnoff N, Sandherr M, Schneller F, Peschel C. Thrombotic thrombocytopenic purpura in metastatic carcinoma of the breast. Am J Clin Oncol. 2000; 23: 74-77.

PubMed: https://pubmed.ncbi.nlm.nih.gov/10683084/

7. Brain MC, Dacie JV, Hourihane DO. Microangiopathic haemolytic anaemia: the possible role of vascular lesions in pathogenesis. $\mathrm{Br} \mathrm{J}$ Haematol. 1962; 8: 358-374.

PubMed: https://pubmed.ncbi.nlm.nih.gov/14014893/

8. Antman KH, Skarin AT, Mayer RJ, Hargreaves HK, Canellos GP Microangiopathic hemolytic anemia and cancer: a review. Medicine. 1979; 58: 377-384.

PubMed: https://pubmed.ncbi.nlm.nih.gov/481196/

9. Chalasani P, Segar JM, Marron M, Stopeck A. Pathophysiology of tumour-induced microangiopathic haemolytic anaemia. BMJ Case Rep. 2016; 2016: bcr2015213521.

PubMed: https://pubmed.ncbi.nlm.nih.gov/26744538/

10. Contrino J, Hair G, Kreutzer DL, Rickles FR. In situ detection of tissue factor in vascular endothelial cells: correlation with the malignant phenotype of human breast disease. Nat Med. 1996; 2: 209-215. PubMed: https://pubmed.ncbi.nlm.nih.gov/8574967/

11. Levi M. Cancer and DIC. Haemostasis. 2001; 31 Suppl 1: 47-48. PubMed: https://pubmed.ncbi.nlm.nih.gov/11990477/

12. Brain MC, Azzopardi JG, Baker LR, Pineo GF, Roberts PD, Dacie JV. Microangiopathic haemolytic anaemia and mucin-forming adenocarcinoma. Br J Haematol. 1970; 18: 183-193.

PubMed: https://pubmed.ncbi.nlm.nih.gov/5439525/

13. Pineo GF, Regoeczi E, Hatton MW, Brain MC. The activation of coagulation by extracts of mucus: a possible pathway of intravascular coagulation accompanying adenocarcinomas. J Lab Clin Med. 1973; 82: 255-266

PubMed: https://pubmed.ncbi.nlm.nih.gov/4352814/

14. Shao B, Wahrenbrock MG, Yao L, David T, Coughlin SR, et al. Carcinoma mucins trigger reciprocal activation of platelets and neutrophils in a murine model of Trousseau syndrome. Blood. 2011; 118: 4015-4023.

PubMed: https://pubmed.ncbi.nlm.nih.gov/21860019/

15. Scully M, Hunt BJ, Benjamin S, Liesner R, Rose P, et al. Guidelines on the diagnosis and management of thrombotic thrombocytopenic purpura and other thrombotic microangiopathies. $\mathrm{Br} \mathrm{J}$ Haematol. 2012; 158: 323-335.

PubMed: https://pubmed.ncbi.nlm.nih.gov/22624596/

16. Caramello V, Dovio A, Caraci P, Berruti A, Angeli A. Thrombotic thrombocytopenic purpura in advanced prostate cancer: case report and published work review. Int J Urol. 2007;14: 150-152.

PubMed: https://pubmed.ncbi.nlm.nih.gov/17302573/

17. Basic-Jukic N, Kes P, Bubic-Filipi L, BrunettaB. Treatment of thrombotic microangiopathieswith plasmaexchange. Hematology.2007;12:63-67. PubMed: https://pubmed.ncbi.nlm.nih.gov/17364995/

18. Subramaniam S, Choufani E, Manov A. Lack of energy, petechiae, elevated PSA level--Dx? J Fam Pract. 2014; 63: 565-567.

PubMed: https://pubmed.ncbi.nlm.nih.gov/25343154/

19. Innes A, Bernard T, Cotton RE, Burden RP. Recurrent haemolytic uraemic syndrome in the elderly associated with metastatic carcinoma. Nephrology, dialysis, transplantation: official publication of the European Dialysis and Transplant Association. Nephrol Dial Transplant. 1990; 5: 886-888.

PubMed: https://pubmed.ncbi.nlm.nih.gov/2128386/

20. Van der Merwe WM, Collins JF. The haemolytic uraemic syndrome and prostatic carcinoma. N Z Med J. 1987;100: 483-485.

PubMed: https://pubmed.ncbi.nlm.nih.gov/3455512/

21. Sennesael JJ, Vanden Houte KM, Spapen HD, de Bruyne RM, Verbeelen DL. Recurrent hemolytic uremic syndrome and metastatic malignancy. Am J Nephrol. 1987; 7: 60-64.

PubMed: https://www.ncbi.nlm.nih.gov/pubmed/3578376
22. Biers SM, Sullivan ME, Roberts IS, Noble JG. Thrombotic microangiopathy in advanced prostatic carcinoma. Urology. 2004; 63: 380-382.

PubMed: https://pubmed.ncbi.nlm.nih.gov/14972503/

23. Kanesvaran R, Phipps C, Cheng CW, Chan MM, Khoo D, Tan MH. Management of thrombotic thrombocytopenic purpura in metastatic prostate cancer with only endocrine therapy. Annals of the Academy of Medicine, Singapore. 2010; 39: 580-582.

PubMed: https://www.ncbi.nlm.nih.gov/pmc/articles/PMC6732406/

24. Perkovic V, Came NA, Grigg AP, Becker GJ. Haemolytic uraemic syndrome and prostatic cancer. Aust N Z J Med. 1999; 29: 383-384. PubMed: https://pubmed.ncbi.nlm.nih.gov/10868509/

25. Furlan M, Robles R, Galbusera M, Remuzzi G, Kyrle PA, Brenner B, et al. von Willebrand factor-cleaving protease in thrombotic thrombocytopenic purpura and the hemolytic-uremic syndrome. N Engl J Med. 1998; 339: 1578-1584.

PubMed: https://pubmed.ncbi.nlm.nih.gov/9828245/

26. Lammle B, Kremer Hovinga JA, George JN. Acquired thrombotic thrombocytopenic purpura: ADAMTS13 activity, anti-ADAMTS13 autoantibodies and risk of recurrent disease. Haematologica. 2008; 93: 172-177.

PubMed: https://pubmed.ncbi.nlm.nih.gov/18245649/

27. Peyvandi F, Ferrari S, Lavoretano S, Canciani MT, Mannucci PM. von Willebrand factor cleaving protease (ADAMTS-13) and ADAMTS-13 neutralizing autoantibodies in 100 patients with thrombotic thrombocytopenic purpura. $\mathrm{Br} J$ Haematol. 2004; 127: 433-439. PubMed: https://pubmed.ncbi.nlm.nih.gov/15521921/

28. Ono T, Mimuro J, Madoiwa S, Soejima K, Kashiwakura Y, Ishiwata A, et al. Severe secondary deficiency of von Willebrand factor-cleaving protease (ADAMTS13) in patients with sepsis-induced disseminated intravascular coagulation: its correlation with development of renal failure. Blood. 2006; 107: 528-534.

PubMed: https://pubmed.ncbi.nIm.nih.gov/16189276/

29. Vesely SK, George JN, Lammle B, Studt JD, Alberio L, El-Harake MA, et al. ADAMTS13 activity in thrombotic thrombocytopenic purpurahemolytic uremic syndrome: relation to presenting features and clinical outcomes in a prospective cohort of 142 patients. Blood. 2003; 102: 60-68.

PubMed: https://pubmed.ncbi.nlm.nih.gov/12637323/

30. George JN. Measuring ADAMTS13 activity in patients with suspected thrombotic thrombocytopenic purpura: when, how, and why? Transfusion. 2015; 55: 11-13.

PubMed: https://www.ncbi.nlm.nih.gov/pmc/articles/PMC4295634/

31. George JN, Vesely SK, Terrell DR. The Oklahoma Thrombotic Thrombocytopenic Purpura-Hemolytic Uremic Syndrome (TTPHUS) Registry: a community perspective of patients with clinically diagnosed TTP-HUS. Seminars in hematology. 2004; 41: 60-67. PubMed: https://pubmed.ncbi.nlm.nih.gov/14727260/

32. Kremer Hovinga JA, Vesely SK, Terrell DR, Lammle B, George JN. Survival and relapse in patients with thrombotic thrombocytopenic purpura. Blood. 2010; 115:1500-1511.

PubMed: https://pubmed.ncbi.nlm.nih.gov/20032506/

33. Shah N, Rutherford C, Matevosyan K, Shen YM, Sarode R. Role of ADAMTS13 in the management of thrombotic microangiopathies including thrombotic thrombocytopenic purpura (TTP). $\mathrm{Br} \mathrm{J}$ Haematol. 2013; 163: 514-519.

PubMed: https://pubmed.ncbi.nlm.nih.gov/24111495/

34. Forman RB, Benkel SA, Novik Y, Tsai HM. Presence of ADAMTS13 activity in a patient with metastatic cancer and thrombotic microangiopathy. Acta Haematologica. 2003; 109: 150-152.

35. Levy GG, Nichols WC, Lian EC, Foroud T, McClintick JN, McGee BM, et al. Mutations in a member of the ADAMTS gene family cause thrombotic thrombocytopenic purpura. Nature. 2001; 413: 488-494. PubMed: https://pubmed.ncbi.nlm.nih.gov/11586351/ 
36. Fontana S, Gerritsen HE, Kremer Hovinga J, Furlan M, Lammle B. Microangiopathic haemolytic anaemia in metastasizing malignant tumours is not associated with a severe deficiency of the von Willebrand factor-cleaving protease. $\mathrm{Br} \mathrm{J}$ Haematol. 2001; 113: 100-102. PubMed: https://pubmed.ncbi.nlm.nih.gov/11328288/

37. Froehlich-Zahnd R, George JN, Vesely SK, Terrell DR, Aboulfatova K, et al. Evidence for a role of anti-ADAMTS13 autoantibodies despite normal ADAMTS13 activity in recurrent thrombotic thrombocytopenic purpura. Haematologica. 2012; 97: 297-303.

PubMed: https://pubmed.ncbi.nlm.nih.gov/21993669/

38. Lin YC, Chang HK, Sun CF, Shih LY. Microangiopathic hemolytic anemia as an initial presentation of metastatic cancer of unknown primary origin. South Med J. 1995; 88: 683-687.

PubMed: https://pubmed.ncbi.nlm.nih.gov/7777893/

39. Lohrmann HP, Adam W, Heymer B, Kubanek B. Microangiopathic hemolytic anemia in metastatic carcinoma. Report of eight cases. Annals of internal medicine. 1973; 79: 368-375.

PubMed: https://pubmed.ncbi.nlm.nih.gov/4748253/

40. de la Fouchardiere C, Flechon A, Droz JP. Coagulopathy in prostate cancer. The Netherlands journal of medicine. 2003; 61: 347-354. PubMed: https://pubmed.ncbi.nlm.nih.gov/14768717/

41. Nguyen TC, Han YY. Plasma exchange therapy for thrombotic microangiopathies. Organogenesis. 2011; 7: 28-31.

PubMed: https://pubmed.ncbi.nlm.nih.gov/21293177/
42. homas M, Scully M. How I Treat Microangiopathic Hemolytic Anemia in Patients with Cancer. Blood. 2021; 2019003810.

PubMed: https://pubmed.ncbi.nlm.nih.gov/33512445/

43. Vendramin C, McGuckin S, Alwan F, Westwood JP, Thomas M, et al. A single-center prospective study on the safety of plasma exchange procedures using a double-viral-inactivated and prion-reduced solvent/ detergent fresh-frozen plasma as the replacement fluid in the treatment of thrombotic microangiopathy. Transfusion. 2017; 57: 131-136. PubMed: https://pubmed.ncbi.nlm.nih.gov/27774620/

44. Ramos R, Lopes F, Rodrigues T, Rolim N, Rodrigues I, Monteiro H. Advanced prostate cancer presenting as hemolytic uremic syndrome. Case Rep Urol. 2013; 2013: 459618.

PubMed: https://www.ncbi.nlm.nih.gov/pmc/articles/PMC3657421/

45. Mungall S, Mathieson P. Hemolytic uremic syndrome in metastatic adenocarcinomaofthe prostate.Americanjournalofkidneydiseases: the official journal of the National Kidney Foundation. 2002; 40: 1334-1336. PubMed: https://pubmed.ncbi.nIm.nih.gov/12460056/

46. Muller NJ, Pestalozzi BC. Hemolytic uremic syndrome in prostatic carcinoma. Oncology. 1998; 55: 174-176.

PubMed: https://pubmed.ncbi.nlm.nih.gov/9499193/

47. Milutinovic J, Irby S, Fisher M. Hemolytic uremic syndrome and metastatic malignancy. South Med J. 1982; 75: 1409-1411. PubMed: https://pubmed.ncbi.nlm.nih.gov/7146974/ 